\title{
CEO turnover and company performance: Sensitivity and empirical estimates
}

\author{
Svetlana V. Orekhova, Larisa Sh. Kudin, Aleksandra V. Kupera
}

\begin{abstract}
Solving organizational effectiveness problems is largely dependent on the quality of the corporate governance system. One of its main aspects is characteristics and actions of a firm's CEO. The paper evaluates how CEO turnover affects a company's performance. Having conducted a critical analysis of the current approaches describing its role and impact on business success, the authors substantiate the research methodological domain: a synthesis of theories of neoinstitutionalism, organization and strategic management. The research method is panel regression with fixed effects. The information base includes the data from 54,341 Russian joint stock companies for the period 2006-2017. A number of variations of the basic model allowed us to establish a statistically significant negative relationship between the change in revenue and CEO turnover in the short term. The obtained results have confirmed the provisions of the theory of the firm regarding the necessity to adapt a CEO to the company's external and internal environment. The paper shows that foreign CEOs and owners (shareholders) are faster to adapt to a new position, which accelerates the growth of business performance indicators. At the same time, the research demonstrates that a decline in a company's performance has a short-term effect. This means that boards of directors should not take hasty decisions to switch the CEO after a short-term poor performance.
\end{abstract}

Keywords: corporate governance; CEO; company performance; CEO turnover; public company; Russian company.

JEL Classification: C10, G30

Paper submitted: April 18, 2019

For citation: Orekhova S.V., Kudin L.Sh., Kupera A.V. (2019). CEO turnover and company performance: Sensitivity and empirical estimates. Upravlenets - The Manager, 2019, vol. 10, no. 4, pp. 2-13. D0I: 10.29141/2218-5003-2019-10-4-1.

\section{INTRODUCTION}

The development of the system of corporate governance in Russia began with privatization of the first public companies, their evolution to the level of large corporations and access to international markets. Today's geopolitical and economic challenges make it necessary to shift the priorities in the corporate governance system from the outward (external) to the inward (internal) development trajectory. In other words, seeking new mechanisms for organizational effectiveness of Russian corporations is high on the agenda today.

The issue of organizational effectiveness is largely related to the CEO's personality. On the one hand, extensive expertise, skills and awareness of the business specificity suggest the CEO to be deeply integrated into the processes within the company. On the other hand, being employed as a CEO for a long time is able to worsen adaptive and motivational characteristics of a worker.

A CEO is a person who makes strategic decisions regarding investments, production, distribution of resources and access to new markets and bears a large share of responsibility for the company's performance. In most cases, CEO turnover is a shock for the firm, especially if it is unplanned and makes them resign prematurely. A new leader may influence the intercompany and market indicators in an ambiguous manner. At the same time, both growth and decline in the company's performance indicators are possible.

In accordance with the Civil Code (article 65.3), the terms "director", "general director" and "chairman" are interpreted as "the sole executive body in the corporation". The company's charter may stipulate that responsibilities of the single executive body can be distributed between several persons acting together or it is necessary to form several single executive bodies acting independently (para 1, article 53). Both an individual and a legal entity can act as a firm's single executive body.

The Federal Law on public companies no. 208-FZ of December 26, 1995 specifies that "management of a company's current activities is performed by (1) the single executive body of the company (director, general director) or (2) the single executive body of the company (director, general director) and the collegial executive body of the company (board, directorate). The executive bodies report to the company's board of directors (supervisory board) and the shareholders general meeting."

The Russian term "a single executive body" corresponds to the concept of chief executive officer (CEO) used in the English-language literature. Within the framework of the present study, we equate the abovementioned concepts and apply the term "chief executive officer" (CEO).

An analysis of the evolution of corporate governance in Russia confirms that the CEO plays a significant part in a company. In the post-privatization period, one person combined the functions of the owner and the CEO, and it is hardly possible to overestimate their contribution to the company's performance (see, for example, [Tkachenko, 2001; Dubrovsky et al., 2004; Dolgopyatova, 2007]).

The aim of the research is to discuss the Russian specificity and the extent to which CEO turnover affects companies' performance at the current stage of the development of the corporate governance system.

Bearing in mind the aim of the study, the authors clarify some points. Firstly, we provide the theoretical and methodological basis for analysing CEO turnover-performance sensitivity. Secondly, we form the methodical framework of the research. Thirdly, we empirically test how changing a compa- 
ny's CEO influences its performance indicators, and interpret the obtained results.

The sample of the study is 54,341 public companies operating in the territory of the Russian Federation. The data are summarized for the period 2007-2016.

\section{A REVIEW OF THE THEORETICAL APPROACHES TO CEO TURNOVER-PERFORMANCE SENSITIVITY}

In the context of the transformation of traditional business models, the issues of organizational effectiveness, control and administration are gaining in importance. In particular, there is a wide-ranging discussion in the literature on the interrelation between the parameters "CEO turnover" and "company performance". The logical argumentation of this dependence is presented from various theoretical positions (Fig. 1).

According to neoclassical economics, an enterprise acts as a market agent whose behavior is reduced to the choice of the volume, price and structure of the resources attracted to maximize profits. Neoclassical economics provides no explanation for intracompany differences associated with work organization and employee incentives. A company is studied as "a black box", and the role of the leader is estimated indirectly.

Within the framework of new institutional economics, developed by Ronald Coase in 1937, the existence of a company is attributed to savings on transaction costs. The company itself is seen as a team of employees united by common interests, but also pursuing personal interests and prone to opportunism.

Claude Menard defines organization as an economic coordination unit with detectable boundaries and operating more or less continuously to achieve a goal or a set of goals shared by the participating members. In other words, an organization is characterized by a set of participants, agreement or disagreement (hidden or expressed openly) over certain goals and means (contracts, dismissals, strikes, etc.), formal coordination that determines the structure taking into account the degree of its complexity (hierarchy), rules and procedures (formalization) and the degree of centralization (decision making) [Menard, 1996, p. 22]. The leader plays a fundamental role in the formation of the team to implement a strategy and ensure the growth of labor productivity and the company's effectiveness (this ideology underlies a number of modern studies, such as [Fidrmucova, Fidrmuc, 2001; Kato, Long, 2006; Huson, Malatesta, Parrino, 2004; Muravyev, 2003; Fee et al., 2017]).

One of the areas of new institutionalism - the principalagent theory - argues that in a classical corporation (where a pool of shareholders is quite vast), current management of the CEO (agent) is different from that required to maximize the profit of shareholders (principals) [Berle, Means, 1932; Pratt, Zeckhauser, Arrow, 1985]. Due to such management actions, the so-called agency costs may occur, i.e. a decrease in profit if compared to the amount that the owners would receive if they exercised a direct control of the corporation [Jensen, Meckling, 1976].

One of the ways to reduce losses for owners is to apply the mechanisms for incentivizing top executives which imply a financial inducement for complying with shareholders' interests [Eisenhardt, 1989]. For example, senior executives are able to acquire the company's stocks (at a reduced price) [Jensen, Meckling, 1976]. Another option is a deferred compensation, where part of top managers' remuneration is saved for the future to stimulate the growth of corporate value in the long term and prevent agents' short-term predatory actions.

Similarly, contract theory seeks to prevent managerial "opportunistic behavior" which involves senior managers abusing their position and enjoying benefits in addition to the base pay to the detriment of shareholder interests [Williamson, 1985]. The board of directors is the main structural mechanism for reducing opportunism. This body carries out the monitoring of managerial actions on behalf of the shareholders. The control is even more complete, if the chairman of the board of directors is independent of the executive management.

Thus, new institutional theories suggest the following: if the CEO also holds the position of chairman, the owners' interests will be sacrificed in favour of the management, which may lead to managerial opportunism and the loss of the company.

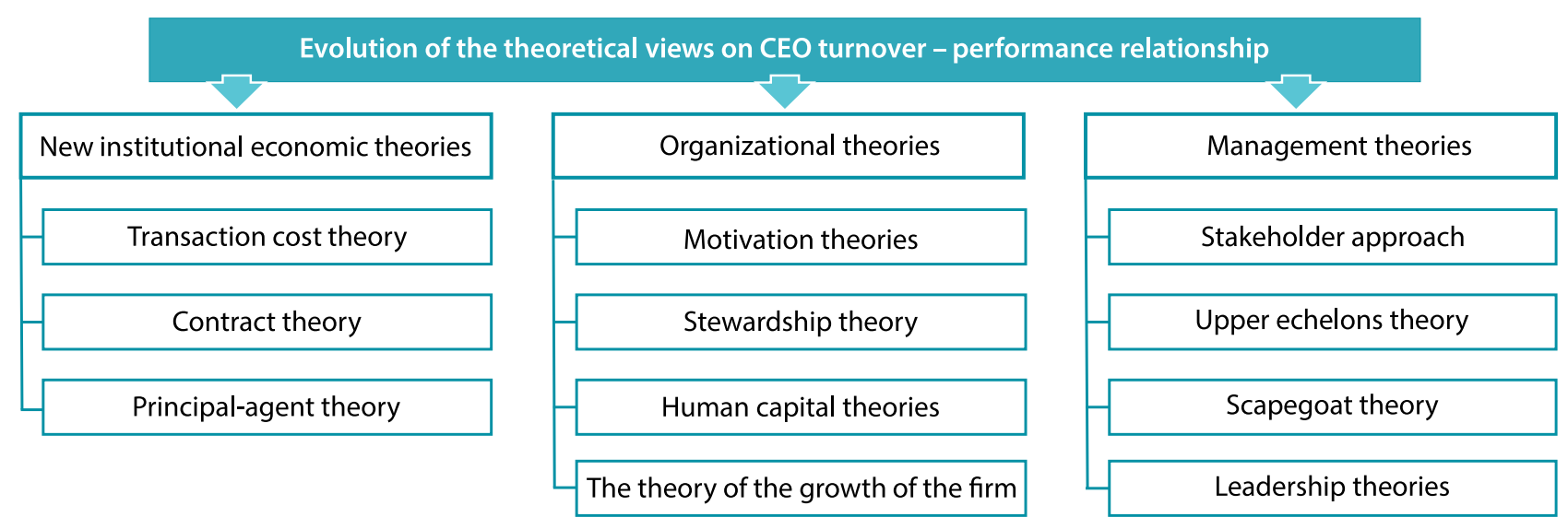

Fig. 1. Evolution of the theoretical views on the CEO turnover-performance relationship 
Agency theory and contract theory are premised on the model of homo economicus who is consistently rational in maximizing self-interest. The concept based on the urge to get a reward and avoid punishment was argued earlier in the system of organization theories and was called "Theory X" [Argyris, McGregor, 1960].

However, there are other motivational "models of man" that originate from organizational psychology and organizational sociology. They rest on the concept of organizational role, that is the mechanism for deriving internal satisfaction through successful completion of a piece of complex work, growing responsibility and authority and thus gaining recognition [Herzberg, Mausner, Snyderman, 1959; McClelland, 1961]. Moreover, the identification of managers with the corporation, especially if they are employed for a long time and participated in its creation, helps combine individual selfesteem with corporate prestige. At that, as noted by Etzioni [1975], even if the company's development is not in line with the manager's interests, they can perform the job out of a sense of duty.

While agency theory clearly and objectively distinguishes between the interests of managers and owners, organizational sociologists (see, for example, [Silverman, 1970]) note that the manager's motivation is based on their personal perception. If a manager realizes that their future well-being is linked with the employer (for instance, in anticipation of labour or pension rights), they can identify their own interests with corporate ones even in the absence of obvious financial motivation.

These considerations justify the existence of alternative managerial motivation presented in stewardship theory [Donaldson, 1990; Barney, 1990]. The authors of the theory suppose that there is no general problem of executive motivation. The CEO is assumed to act in compliance with the company's interests and everything they do is for the good of the firm. Differences in productivity arise from the way in which organizational structure contributes to effective actions of top executives. According to Donaldson [1985; 1990], the effectiveness of the administration organizational structure depends on (1) to what extent it meets the expectations and (2) how wide and "legitimized" top managers' powers are.

Hence, stewardship theory is not aimed at motivating the CEO, but at the overall effectiveness of organizational structures and the system of corporate governance as a whole. The fuller the control of the corporation's CEO, the better performance is expected to be. If an individual combines the functions of the CEO and the chairman of the board of directors, power and responsibility are concentrated in one person, and there is no doubt who is responsible for the decisions made.

The head of the company can also be viewed as a valuable asset that creates a competitive advantage due to their commitment to work, adaptability and work of high quality (skills, ability to work efficiently, etc.). Human capital theory looks at employees' education and expertise, including spe- cial skills and a management talent, as investments that directly influence the company's performance. The theory puts the primary emphasis on comparing personal characteristics of CEOs (see, for example, [Storey, 1989]).

The upper echelons theory [Hambrick, Mason, 1984] echoes the theory of human capital, as it analyses the qualities and characteristics of a person. However, the upper echelons theory focuses on studying the CEO's role in fostering organizational culture and achieving the stated goals. It is postulated that, when processing a massive flow of information, the head filters and simplifies it according to their values and cognitive skills. Due to the fact that these characteristics are rather difficult to evaluate, the upper echelons theory explored them through age and gender and some other parameters. Hambrick and Mason's model demonstrates that a company's performance is linearly dependent on these characteristics of top executives.

A number of studies investigate CEOs' skills (considering their age, overconfidence and management style) from the perspective of their value for companies and how innovative the strategies they develop are. Benmelech and Frydman [2015] note that the fact of serving in the military exerts a marked effect on a CEO's behavior and management style (more conservative). Bertrand and Schoar [2003] argue that young executives holding an MBA degree are more risk averse than top executives of mature years. Kaplan, Klebanov and Sorensen [2012] prove there is a direct relationship between CEO turnover and a company's performance. According to Zhang, Wierschem and Mendez Mediavilla [2016], CEO turnover produces an immediate effect on productivity and the company's stock price.

In contrast to the hypothesis of human capital, scapegoat theory is based on agency models [Mirrlees, 1976; Holmstrom, 1979; Shavell, 1979; Gamson, 1964]. According to this approach, a company's poor performance is more associated with an unfortunate combination of circumstances rather than the quality of management and efforts of the CEO. A forced dismissal of the CEO in this case is a signal for the next leader, who might not differ in their qualities from the dismissed one. As a result, the new top executive makes more efforts, which results in the improvement in the company's performance indicators. Thus, the CEO dismissed for poor performance is not a bad leader but the so-called "scapegoat". Eventually, the performance indicators restore their previous values.

Leadership theories in management have a wide range of research objectives that can be categorized into three groups: theories of leadership qualities, behavioral and situational theories.

One of the situational theories of leadership - transactional and transformational leadership [Burns, 1978] - is of special importance from the standpoint of the effect exerted on a company's performance. This theory was further developed by Tichy and Devanna [1990]. Its central idea is that amid a changing environment leaders take on the burden of the company's reorganization, shape new vision of it and de- 
velop a strategy. These transformations are reflected, among other things, in the company's improving performance.

The late 20th century was marked by the emergence of new leadership theories premised on moral and ethical aspects. While traditional leadership theories are company-oriented, the studies within this group of theories are aimed at changing individuals within a company. From this perspective, new leadership theories largely coincide with approaches of organizational sociology [Goleman, 1995; Lipman-Blumen, 1997].

According to stakeholder theory, managers should not focus on economic performance indicators. Their goal is to enhance the well-being of stakeholders involved in the system of the company's value creation [Freeman, 2010]. According to Yakovlev, Danilov and Simachev [2010, p. 31], a possible example is the Volkswagen Group which applies mostly nonstandard corporate governance mechanisms (with employees and regional authorities represented on the board of directors) and resisted the crisis of 2008 more successfully than other automobile companies.

At the same time, there is a lack of consensus about what a company's performance for stakeholders is (for more details, see [Tkachenko, Zlygostev, 2018]). A number of researchers claim that shareholders should be prioritized among all stakeholders [Berle, Means, 1932; Jensen, 2001], and guaranteeing dividends for shareholders is, therefore, the primary responsibility of a company's top management. Other scientists suppose that stakeholders that provide the company with significant resources are also entitled to part of the surplus value created [Barney, 1990].

For the purposes of our study, we pay special attention to the theory of the growth of the firm developed by Edith Penrose [Penrose, 1955]. The theory postulates that the increasing size of a company is one of the problems in im- plementing management activities. In particular, Penrose claimed that "there must be a size beyond which the services required for its efficient operation simply cannot be supplied by mortal men... The complexity of structure and the scope of activity are believed to become such that even the minimum decisions required of the chief executives in order to ensure the requisite degree of co-ordination are so difficult or so numerous that the firm must suffer in efficiency" [Penrose, 1955, p. 541]. At the moment, the concept of a firm's growth is interpreted as a combination of numerous interdependent and diverse elements that affect decision making and the implementation of growth strategies [Buckley, Casson, 2010; Sargut, McGrath, 2011].

The idea of the theory of the growth of firm is as follows: a company's ability to expand itself is limited by resources, so it can grow due to the CEO's efforts. The CEO's work experience in a particular company can be considered as a universal resource conducive to its growth. Managers benefit from reinvestment. Consequently, they will be encouraged to develop the company as quickly as possible [Penrose, 2009, p. 29]. CEO turnover, on the contrary, can impede the company's growth in the short term, since it will take some time to adapt.

Table 1 combines the main theories and approaches that explain the influence of a company's CEO on its performance. Within the framework of the current study, all the theories are equally important. For example, relying on new institutionalism and agency theory, in particular, is possible from the position of both studying managers' entrenchment and analyzing the convergence of agents and principals' interests.

The upper echelons theory will allow assessing the effect of CEOs' characteristics on the company's performance. The theory of the growth of the firm takes into account the complexity of the company's external and internal environment that affects its performance when a new CEO takes office.

Table 1 - Comparative analysis of theories explaining the influence of a company's CEO on its performance Таблица 1 - Сравнительный анализ теорий, объясняющих влияние генерального директора на результативность деятельности компании

\begin{tabular}{|c|c|c|c|c|c|c|c|c|}
\hline $\begin{array}{c}\text { Criterion } \\
\text { for comparing }\end{array}$ & $\begin{array}{l}\text { Agency } \\
\text { theory }\end{array}$ & $\begin{array}{c}\text { Organizational } \\
\text { theory }\end{array}$ & $\begin{array}{c}\text { Stewardship } \\
\text { theory }\end{array}$ & $\begin{array}{l}\text { Upper } \\
\text { echelons } \\
\text { theory }\end{array}$ & $\begin{array}{c}\text { Theory } \\
\text { of the growth } \\
\text { of the firm }\end{array}$ & $\begin{array}{c}\text { Transformational } \\
\text { leadership } \\
\text { theory }\end{array}$ & $\begin{array}{c}\text { Stakeholder } \\
\text { theory }\end{array}$ & $\begin{array}{c}\text { Scapegoat } \\
\text { theory }\end{array}$ \\
\hline $\begin{array}{l}\text { Unit of } \\
\text { analysis }\end{array}$ & Agency costs & $\begin{array}{l}\text { Possibility } \\
\text { to control } \\
\text { and run } \\
\text { the company }\end{array}$ & $\begin{array}{l}\text { Activity spe- } \\
\text { cialization }\end{array}$ & $\begin{array}{l}\text { Cognitive } \\
\text { ability }\end{array}$ & $\begin{array}{l}\text { The firm's } \\
\text { growth }\end{array}$ & $\begin{array}{l}\text { Leadership } \\
\text { qualities }\end{array}$ & $\begin{array}{l}\text { Stake- } \\
\text { holders' } \\
\text { interests }\end{array}$ & $\begin{array}{l}\text { Change } \\
\text { of manager }\end{array}$ \\
\hline $\begin{array}{l}\text { Effect of CEO } \\
\text { turnover } \\
\text { on the com- } \\
\text { pany's perfor- } \\
\text { mance }\end{array}$ & $\begin{array}{l}\text { Studied indi- } \\
\text { rectly, } \\
\text { can be posi- } \\
\text { tive (under } \\
\text { opportunism } \\
\text { and en- } \\
\text { trenchment) }\end{array}$ & \begin{tabular}{|l|} 
Studied \\
indirectly, \\
can be \\
positive (if the \\
board \\
of directors \\
is weak)
\end{tabular} & $\begin{array}{l}\text { Studied } \\
\text { indirectly, } \\
\text { negative }\end{array}$ & \begin{tabular}{|l} 
Studied \\
indirectly, \\
dependent \\
on the CEO's \\
personal \\
characteris- \\
tics
\end{tabular} & Negative & $\begin{array}{l}\text { Studied } \\
\text { indirectly, } \\
\text { dependent } \\
\text { on leadership } \\
\text { qualities }\end{array}$ & $\begin{array}{l}\text { Studied } \\
\text { indirectly, } \\
\text { dependent } \\
\text { on the bal- } \\
\text { ance } \\
\text { of interests }\end{array}$ & Positive \\
\hline $\begin{array}{l}\text { Opportunities } \\
\text { for enhancing } \\
\text { the company's } \\
\text { performance }\end{array}$ & $\begin{array}{l}\text { Acquiring the } \\
\text { company's } \\
\text { stocks by the } \\
\text { CEO; deferred } \\
\text { compensa- } \\
\text { tion }\end{array}$ & $\begin{array}{l}\text { The CEO's } \\
\text { actions are } \\
\text { supervised by } \\
\text { the board of } \\
\text { directors }\end{array}$ & $\begin{array}{l}\text { The CEO } \\
\text { combines } \\
\text { management } \\
\text { and control } \\
\text { functions }\end{array}$ & $\begin{array}{l}\text { Selecting } \\
\text { the CEO with } \\
\text { particular } \\
\text { characteris- } \\
\text { tics }\end{array}$ & $\begin{array}{l}\text { Expertise } \\
\text { and working } \\
\text { experience } \\
\text { of the CEO }\end{array}$ & $\begin{array}{l}\text { Overcoming } \\
\text { resistance to } \\
\text { change as one } \\
\text { of the leader's } \\
\text { qualities }\end{array}$ & $\begin{array}{l}\text { Participa- } \\
\text { tion of key } \\
\text { stakehold- } \\
\text { ers in com- } \\
\text { pany man- } \\
\text { agement }\end{array}$ & $\begin{array}{l}\text { CEO } \\
\text { turnover }\end{array}$ \\
\hline
\end{tabular}


THE METHOD FOR STUDYING CEO TURNOVER-COMPANY

\section{PERFORMANCE SENSITIVITY}

There are numerous research studies evaluating the influence of CEO turnover on the company's performance (see, for example, [Bonnier, Bruner, 1989; Khanna, Poulsen, 1995; Crespí-Cladera, Pascual-Fuster, 2015; Fiordelisi, Ricci, 2014; Jenter, Lewellen, 2017; Jenter, Kanaan, 2015; Gao, Harford, Li, 2017], etc.). Most studies confirm that there is a statistically significant relationship between companies' performance and turnover of their CEOs. At the same time, the polemics on some significant points makes us suppose that the turnover-performance issue is not yet fully resolved. Firstly, it is worth noting that various indicators of productivity and production efficiency of enterprises are applied in the context of turnover-performance sensitivity (Table 2).

Table 2 - Performance indicators used in assessing the impact of CEO turnover

Таблица 2 - Показатели результативности, используемые при оценке влияния смены генерального директора

\begin{tabular}{|l|l|}
\hline \multicolumn{1}{|c|}{ Author(s) } & \multicolumn{1}{|c|}{ Performance indicator(s) } \\
\hline Fidrmucova, Fidrmuc [2001] & $\begin{array}{l}\text { Total sales; } \\
\text { fixed assets }\end{array}$ \\
\hline Muravyev [2017] & $\begin{array}{l}\text { Market-to-book ratio; } \\
\text { the market value of a company } \\
\text { divided by its assets' } \\
\text { replacement cost (Tobin's Q); } \\
\text { return on equity (ROE); } \\
\text { return on assets (ROA) }\end{array}$ \\
\hline Gibson [2003] & $\begin{array}{l}\text { Earnings scaled by assets; } \\
\text { change in earnings scaled by } \\
\text { lagged assets; } \\
\text { stock market return; } \\
\text { growth in sales }\end{array}$ \\
\hline $\begin{array}{l}\text { Shen, Cannella [2002], } \\
\text { Fussalli, Cukurova [2018], } \\
\text { Fiordelisi, Ricci [2014] }\end{array}$ & $\begin{array}{l}\text { Return on assets (ROA); } \\
\text { industry-adjusted ROA, IAROA }\end{array}$ \\
\hline $\begin{array}{l}\text { Crespí-Cladera, Pascual- } \\
\text { Fuster [2015] }\end{array}$ & $\begin{array}{l}\text { Return on assets (ROA); } \\
\text { return on equity (ROE); } \\
\text { market-to-book ratio; } \\
\text { stock return; } \\
\text { assets; } \\
\text { sales volume; } \\
\text { market value; } \\
\text { number of employees }\end{array}$ \\
\hline Denis, Denis [1995] & $\begin{array}{l}\text { Operating performance } \\
\text { in leveraged buyouts (LBOs) }\end{array}$ \\
\hline $\begin{array}{l}\text { Operating rate of return } \\
\text { on total assets (OROA); } \\
\text { operating income before } \\
\text { depreciation to total assets } \\
\text { (OlBD/TA) }\end{array}$ \\
\hline
\end{tabular}

Secondly, research results show significant cross-country differentiation. Thus, positive effects of CEO turnover on performance are typical mainly of developed countries [Denis, Denis, 1995; Huson, Malatesta, Parrino, 2004; Bonnier, Bruner, 1989] rather than developing nations which demonstrate no significant effect [Setiawan, Phua, Chee, 2017; Lindrianasari, Hartono, 2011].
Thirdly, research findings can also vary depending on the firms selected. For example, to analyse publicly traded companies, it is possible to utilize daily indicators, which determines calculation methods. Two models used here are Bayesian model [Jenter, Kanaan, 2015] and event study [Byrka-Kita, Czerwiński, Preś-Perepeczo, 2017].

Byrka-Kita, Czerwiński and Preś-Perepeczo [2017] notice that investors can revise their evaluations and expectations about stock price if the company announces a CEO rotation. At that, share prices can increase [Bonnier, Bruner, 1989], since investors can treat a CEO rotation as a good sign for enhancing productivity, or fall [Khanna, Poulsen, 1995], if a change in a CEO position indicates that the enterprise is experiencing problems.

To analyse companies, the shares of which are not traded on a stock exchange, internal financial reports are used. In this case, panel data regression is the most widespread and generally recognized evaluation method. The results of empirical evaluations show mainly an improvement in performance after a change in a CEO position [Denis, Denis, 1995; Huson, Malatesta, Parrino, 2004].

In Russia, the interest of researchers is focused on the inverse relationship, i.e. how company performance influences CEO turnover [Goltsman, 2000; Roshchin, Solntsev, 2005; Kapelyushnikov, Demina, 2005; Muravyov et al., 2009; Dolgopyatova, 2011; Solntsev, 2013; Kapelyushnikov, 2015]. They revealed the correlation between a company's performance and a CEO rotation; however, the results are mixed. In addition, most studies were conducted using small samples and/or with the help of survey data.

Rachinskiy [2001] explores the effect of CEO turnover on a company's performance using the data for 1998 regarding 110 Russian publicly traded firms, in which there were 24 changes in CEO positions. The findings illustrate higher stock return in companies that initiated a CEO rotation.

Hence, previous research studies have revealed a number of gaps in examining CEO turnover-performance sensitivity.

There is no consensus on the effect (positive or negative) of CEO turnover on a company's performance. Most sources highlight that a company usually changes its CEO, when its performance indicators go down and the responsibility of the board of directors is to replace the CEO. At the same time, the arrival of a new top manager creates the potential for positive strategic changes.

There are no Russian studies on CEO turnover-performance sensitivity based on a broad data set.

There is no in-depth analysis of the dynamic processes determining steady trends in identifying the CEO turnovercompany performance interrelationship.

The abovementioned specificity proves it to be expedient to apply panel data regression methods. Panel data contain two components - cross-sectional (a significant number of companies) and temporal (time). If it is a non-traded firm, then in the majority of observations there are only annual financial reports. It is necessary, therefore, to monitor changes in a company's performance over a prolonged period of time. 
Panel data regression methods suggest using a model with either fixed or random effects. It is often difficult to imagine a situation, where there is only one possible way, in which explanatory characteristics predetermine changes in a company's performance. To a large extent, the same explanatory characteristics correlate with latent variables. The solution to this problem is to use a model with fixed effects. Then the model will have the following form

Performance $_{i, t}=a_{i}+\beta_{1}$ CEO turnover $_{i, t}+\beta_{2}$ Firm controls $_{i, t}+$ $+\beta_{3} C E O$ controls $s_{i, t}+$ Industry $F E+$ Year $F E+$ Region $F E+\varepsilon_{i, t}$

where Performance ${ }_{i, t}$ denotes a firm's performance; CEO turnover $_{i, t}$ is a dummy variable of CEO turnover; Firm controls $s_{i, t}$ are a firm's characteristics (firm size by log of assets); CEO controls $s_{i, t}$ are a CEO's characteristics (concurrent service, citizenship, gender, owning company shares); Region $F E$, Industry $F E$, Year FE denote fixed effects for the region, sector, year; $a_{i}$ is an individual effect of firm $i$.

The method makes it possible to eliminate the impact of latent effects and obtain unbiased estimates of parameters. The method is considered traditional when studying heterogeneous objects, and for the control of effects not observed in time, temporal fixed effects are also included in the model.

\section{EMPIRICAL TESTING}

\section{OF CEO TURNOVER-PERFORMANCE SENSITIVITY}

The information base of the research is the company data from Ruslana database by bureau Van DIJK that contains comprehensive financial information on Russian companies, top managers, boards of directors and owners.

The sample compiles financial and management information on public companies in Russia due to the fact that their record-keeping activities are most regulated and their data are expected to be of high quality. The final sample is the unbalanced panel dataset and contains data on 54,341 public companies for 2007-2016. Industry-specific and regional characteristics of the sample vary.

Fig. 2 presents the algorithm for identifying the CEO from the list of a company's top managers.

We have conducted a procedure for selecting the data on appointment and resignation of CEOs that is necessary to determine CEO turnover. While financial reports are prepared annually, a CEO may take office any day. In some cases, this created the problem of determining the CEO for a particular year, which was solved in the following way: if the CEO held the post throughout the year, they were recorded as the company's CEO this year; if during the year the top executive was replaced, the CEO holding the position for at least 6 months was selected for the study.

The given procedure allowed us to identify the CEO rotation, which is a fictitious variable that takes on the value 1 , if there was a change in a CEO position at company $i$ in the year $t$.

The dependent variables (a company's performance) are the natural log of revenue, revenue growth rate (change in the natural log of revenue) and a similar indicator with a oneyear lag. We assume that revenue is the most suitable criterion for evaluating a CEO's activity, as it reflects changes in performance compared to the previous periods. A lag-based approach to revenue growth rate is due to lagging effects of the CEO's adaptation to the internal and external environment of the company.

As control variables, we use dummy variables that characterize the industry and regional affiliation of the company, temporal fixed effects, as well as the size of the firm expressed by the natural log of assets.

The explanatory variables, in addition to the main one - a change in the CEO position - are other characteristics, such as length of service, gender, age, number of concurrent positions alongside the one under examination, as well as whether the CEO holds the company's shares, and whether the CEO is a foreigner.

Table 3 presents descriptive statistics of observed variables.

The analysis of descriptive statistics indicates that in $6.7 \%$ of cases there was a change in a CEO position.

The company's size, expressed by the natural logarithm of assets, has a large variance, which signifies that there are both very large and rather small companies in the sample.

A statistically average CEO exhibits the following characteristics:

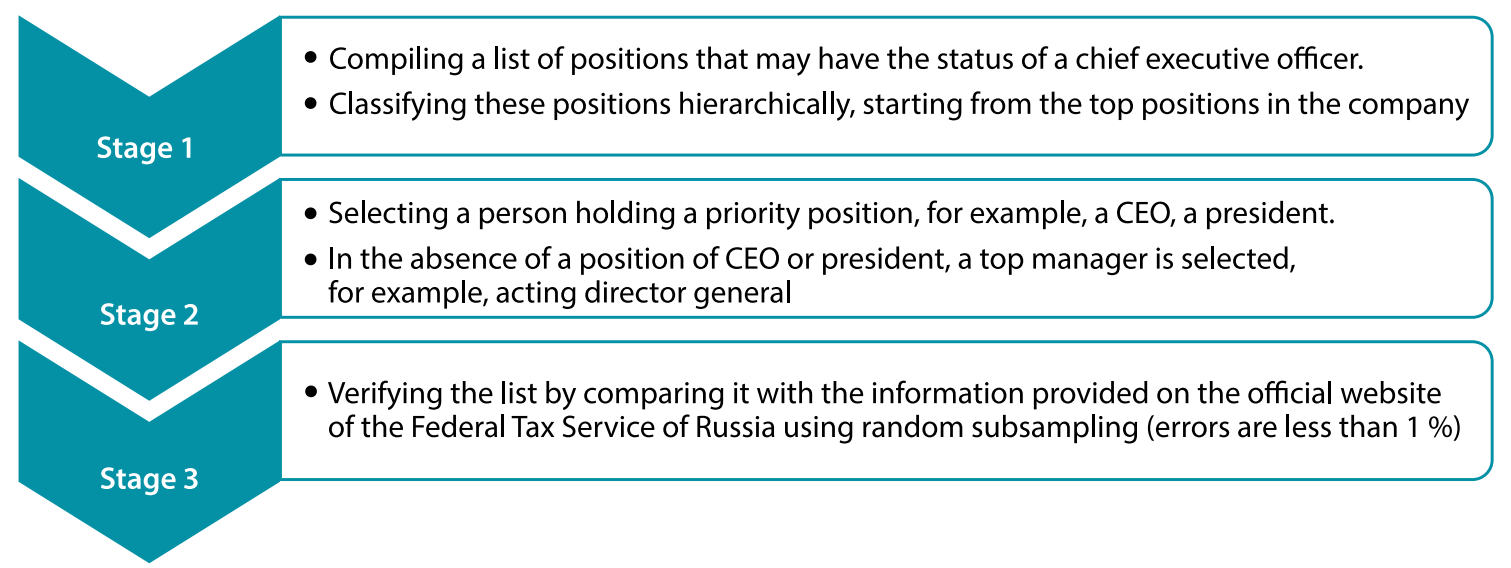

Fig. 2. Algorithm for identifying the CEO from the list of a company's top managers Рис. 2. Алгоритм выявления генерального Аиректора из списка топ-менеджмента компании 

Таблица 3 - Дескриптивная статистика наблюдаемых переменных

\begin{tabular}{|l|c|c|c|c|c|}
\hline \multicolumn{1}{|c|}{ Variable } & $\begin{array}{c}\text { Number } \\
\text { of observations }\end{array}$ & Mean & $\begin{array}{c}\text { Standard } \\
\text { error }\end{array}$ & Minimum value & Maximum value \\
\hline CEO turnover & 422434 & 0.0666 & 0.2493 & 0 & 1 \\
\hline Natural log of revenue & 283111 & 3.5476 & 2.5015 & -10.2046 & 17.0022 \\
\hline Change in the natural log of revenue & 254579 & 0.0331 & 0.6347 & -2.1172 & 2.5914 \\
\hline Natural log of assets & 326350 & 3.2509 & 2.8893 & -11.5129 & 16.6518 \\
\hline Length of service, years & 422433 & 5.1718 & 3.6132 & 0.6 & 16.3 \\
\hline CEO's age, years & 78609 & 48.3350 & 10.1204 & 18 & 92 \\
\hline Number of concurrent positions & 422417 & 2.0751 & 3.3441 & 0 & 156 \\
\hline CEO as a shareholder & 422434 & 0.3291 & 0.4699 & 0 & 1 \\
\hline CEO is a foreigner & 422434 & 0.0439 & 0.2050 & 0 & 1 \\
\hline CEO gender: female - 1, male - 0 & 421586 & 0.1599 & 0.3665 & 0 & 1 \\
\hline
\end{tabular}
with the minimum of less than a year and the maximum of 16 years;

- average age is 48 years ranging from 18 to 92 ;

- an interesting fact is that the average number of concurrent positions held in addition to the one under examination is two posts;

- about 33\% of the CEOs hold shares of their companies;

- $16 \%$ of the CEOs are females;
- average length of service in the CEO position is 5 years

- only $4 \%$ of the CEOs are foreigners.

The results of the basic model regression analysis are presented in Table 4.

The results of the regression analysis show that in the short term CEO turnover exerts a negative effect on the company's performance. It is noteworthy that when considering the changes in sales with a one-year lag, the significance of a CEO rotation and its influence decrease.

Table 4 - Results of the regression analysis Таблица 4 - Результаты регрессионного анализа

\begin{tabular}{|c|c|c|c|}
\hline \multirow[b]{2}{*}{ Variable } & \multicolumn{3}{|c|}{ Specification } \\
\hline & Log of revenue & $\begin{array}{l}\text { Change in log of revenue } \\
\text { to the previous year }\end{array}$ & $\begin{array}{c}\text { Change in log of revenue } \\
\text { to the previous year with } \\
\text { a one-year lag }\end{array}$ \\
\hline $\begin{array}{l}\text { CEO turnover: dummy variable, if there was a change } \\
\text { during the period under observation }-1 \text {, otherwise }-0\end{array}$ & $\begin{array}{c}-0.0359 * * * \\
(0.00695)\end{array}$ & $\begin{array}{c}-0.0393 * * * \\
(0.00555)\end{array}$ & $\begin{array}{l}-0.0105 * \\
(0.00602)\end{array}$ \\
\hline Gender: female -1 , male -0 & $\begin{array}{c}0.0172 \\
(0.0136)\end{array}$ & $\begin{array}{c}0.0107 \\
(0.0112)\end{array}$ & $\begin{array}{c}0.0153 \\
(0.0126)\end{array}$ \\
\hline Length of service & $\begin{array}{c}0.00571 * * * \\
(0.00104)\end{array}$ & $\begin{array}{c}-0.00336 * * * \\
(0.000832)\end{array}$ & $\begin{array}{c}0.000438 \\
(0.000885)\end{array}$ \\
\hline CEO is a foreigner -1 , otherwise -0 & $\begin{array}{c}-0.0460 * * \\
(0.0185)\end{array}$ & $\begin{array}{c}0.0856 * * * \\
(0.0153)\end{array}$ & $\begin{array}{c}0.0621 * * * \\
(0.0176)\end{array}$ \\
\hline CEO is a shareholder -1 , otherwise - 0 & $\begin{array}{l}0.00550 \\
(0.0152)\end{array}$ & $\begin{array}{l}0.0630 * * * \\
(0.0126)\end{array}$ & $\begin{array}{c}0.0428 * * * \\
(0.0140)\end{array}$ \\
\hline Number of concurrent positions & $\begin{array}{c}-0.0907 * * * \\
(0.0103)\end{array}$ & $\begin{array}{l}-0.00717 \\
(0.00834)\end{array}$ & $\begin{array}{c}-0.0265 * * * \\
(0.00928)\end{array}$ \\
\hline Log of assets & $\begin{array}{l}0.628 * * * \\
(0.00252)\end{array}$ & $\begin{array}{l}0.119 * * * \\
(0.00229)\end{array}$ & $\begin{array}{c}0.0913 * * * \\
(0.00259)\end{array}$ \\
\hline Control variables for the industry & Yes & Yes & Yes \\
\hline Control variables for the region & Yes & Yes & Yes \\
\hline Control variables for the year & Yes & Yes & Yes \\
\hline Constant & $\begin{array}{c}1.386 * * * \\
(0.0372)\end{array}$ & $\begin{array}{l}0.00357 \\
(0.0420)\end{array}$ & $\begin{array}{c}0.0915 * * \\
(0.0442)\end{array}$ \\
\hline Number of observations & 280699 & 252464 & 211649 \\
\hline Number of companies & 46404 & 44642 & 42916 \\
\hline R-squared & 0.217 & 0.039 & 0.032 \\
\hline
\end{tabular}

Note. Standard errors are indicated in parentheses: *** $p<0.01, * * p<0.05, * p<0.1$. 
Thus, Edith Penrose's theory of the growth of the firm is confirmed. There is no reason to suppose that any theories turned out to be untenable, since their verification requires other tests and analysis methods to be applied. The significant influence of the CEO's observed characteristics confirms the positions of the upper echelons theory and the convergence of interests of agency theory.

Firstly, it is of interest that a foreign CEO is more adaptable to the new company's environment demonstrating weak performance during the first year of work and improving results in subsequent periods. This might be due to the adaptation of the foreign top manager to the specificity of the corporate culture in Russia.

Secondly, if the top executive holds the company's shares, there is a decline in the firm's performance during the first year and a rise in its performance in subsequent periods. A possible explanation to this fact is that there exists a mechanism for smoothing the opportunistic behaviour, since the CEO acts as an agent and a principal at the same time.

The number of concurrent positions of the CEO displays a variable result, but generally exerts a negative effect on performance. This might be due to poor motivation of the CEO having alternative sources of income. The CEO's gender was insignificant.

\section{CONCLUSION}

The research works on CEO turnover-company performance sensitivity, despite being quite numerous, produce fragmented and contradictory results.

Having conducted the critical analysis of the available approaches to assessing the CEO's role in the company's success, we have identified the reasons behind the relationship between a CEO rotation and the company's performance. The empirical testing based on the data from Russian public companies confirms that there is a significant correlation. At that, the obtained results indicate that in the short term after a change in the CEO position the company's performance does not improve. CEO turnover has a negative effect on the firm's business results.

Bearing this in mind, the boards of directors should avoid taking hasty decisions about a CEO rotation in the situations, where more attention has to be paid to assessing the performance of CEOs, especially in the face of external institutional shocks.

Identifying the factors behind the decrease in a company's performance is one of the promising domains for further research.

\section{References}

Goltsman M.M. (2000). Empiricheskiy analiz smeny menedzherov v rossiyskikh firmakh [An empirical analysis of CEO turnover in Russian firms]. Moscow: Rossiyskaya ekonomicheskaya shkola Publ.

Dolgopyatova T.G. (2007). Empiricheskiy analiz korporativnogo kontrolya v rossiyskikh kompaniyakh: kogda krupnye aktsionery otkhodyat ot ispolnitel'nogo upravleniya? [An empirical analysis of corporate control in Russian companies: when do large shareholders move away from executive management?]. Rossiyskiy zhurnal menedzhmenta - Russian Management Journal, vol. 5, no. 3, pp. 27-52.

Dolgopyatova T.G. (2011). Naemnye menedzhery v rossiyskikh kompaniyakh: empiricheskie svidetel'stva na fone krizisa [External managers in Russian companies: empirical evidence against the backdrop of the crisis]. Finansy $i$ biznes - Finance and Business, no. 4, pp. 149-165.

Dubrovskiy V.Zh., Romanova O.A., Tatarkin A.I., Tkachenko I.N. (2004). Dinamika korporativnogo razvitiya [Dynamics of corporate development]. Moscow: Nauka.

Kapelyushnikov R.I. (2015). Mobil'nost' i identichnost' rukovoditeley rossiyskikh promyshlennykh predpriyatiy [Mobility and identity of managers of Russian industrial enterprises]. Moscow: HSE Publishing House.

Kapelyushnikov R.I., Demina N.V. (2005). Obnovlenie vysshego menedzhmenta rossiyskikh promyshlennykh predpriyatiy: svidetel'stva «Rossiyskogo ekonomicheskogo barometra» [Reorganizing the top management of Russian industrial enterprises: evidence of the "Russian Economic Barometer"]. Rossiyskiy zhurnal menedzhmenta - Russian Management Journal, vol. 3, no. 3, pp. 27-42.

Menar K. (1996). Ekonomika organizatsiy [Enterprises economics]. Moscow: INFRA-M.

Muravyev A.A., Talavera A.V., Bilyk O.A., Grechanyuk B.V. (2009). Rezul'taty deyatel'nosti firm i smena menedzherov v Ukraine [Companies' performance and CEO turnover in Ukraine]. Rossiyskiy zhurnal menedzhmenta - Russian Management Journal, vol. 7, no. 4, pp. 13-32.

Rachinskiy A.A. (2001). Smena menedzherov i effektivnost' kompaniy v Rossii [CEO turnover and companies effectiveness in Russia]. Moscow: Rossiyskaya ekonomicheskaya shkola Publ.

Roshchin S.Yu., Solntsev S.A. (2005). Rynok truda top-menedzherov v Rossii: mezhdu vneshnim naymom i vnutrennim prodvizheniem [The labor market of top managers in Russia: between external hiring and internal promotion]. Rossiyskiy zhurnal menedzhmenta - Russian Management Journal, vol. 3, no. 4, pp. 11-28.

Solntsev S.A. (2013). Izmeneniya na rossiyskom rynke truda top-menedzherov v period krizisa: svidetel'stva empiricheskogo issledovaniya [Changes in the Russian labor market of top managers during the crisis: evidence of empirical research]. Rossiyskiy zhurnal menedzhmenta - Russian Management Journal, vol. 11, no. 1, pp. 3-18. 
Tichy N., Devanna M.A. (1990). The transformational leader (Russ. ed.: Tichy N., Devanna M.A. (1990). Lidery reorganizatsii (iz opyta amerikanskikh korporatsiy Moscow: Ekonomika).

Tkachenko I.N. (2001). Evolyutsiya vnutrifirmennykh korporativnykh otnosheniy [Evolution of intrafirm corporate relationships]. Ekaterinburg: Institute of Economics of the Ural Branch of the RAS.

Tkachenko I.N., Zlygostev A.A. (2018). Otsenka vklada steykkholderov v stoimost' kompanii: primer rossiyskogo bankovskogo sektora [Assessing stakeholders' contribution to enterprise value: the case of the Russian banking sector]. Upravlenets - The Manager, vol. 9, no. 4, pp. 40-52. DOI: 10.29141/2218-5003-2018-9-4-5.

Yakovlev A.A., Danilov Yu.A., Simachev Yu.V. (2010). Global'nyy finansovyy krizis i korporativnoe upravlenie [Global financial crisis and corporate culture]. Rossiyskiy zhurnal menedzhmenta - Russian Management Journal, vol. 8, no. 2, pp. 21-34.

Argyris C., McGregor D. (1960). The Human Side of Enterprise. N.Y.: McGraw-Hill.

Barney J.B. (1990). The debate between traditional management theory and organizational economics: Substantive differences or intergroup conflict? Academy of Management Review, vol. 15, no. 3, pp. 382-393.

Benmelech E., Frydman C. (2015). Military CEOs. Journal of Financial Economics, vol. 117, no. 1, pp. 43-59.

Berle A., Means G. (1932). The modern corporation and private property. N.Y.: McMillan.

Bertrand M., Schoar A. (2003). Managing with style: The effect of managers on firm policies. The Quarterly Journal of Economics, vol. 118, no. 4, pp. 1169-1208.

Bonnier K.A., Bruner R.F. (1989). An analysis of stock price reaction to management change in distressed firms. Journal of Accounting and Economics, vol. 11, no. 1, pp. 95-106.

Buckley P.J., Casson M. (2010). Edith Penrose's theory of the growth of the firm and the strategic management of multinational enterprises. In: Buckley P.J., Casson M. The Multinational Enterprise Revisited. L.: Palgrave Macmillan. Pp. 277-300.

Burns J.M. (1978). Leadership. N.Y.: Harper \& Row.

Byrka-Kita K., Czerwiński M., Preś-Perepeczo A. (2017). Stock market reaction to CEO appointment - preliminary results. Journal of Management and Business Administration, vol. 25, no. 2, pp. 23-42.

Cornelli F., Karakaş O. (2015). CEO turnover in LBOs: The role of boards. SSRN Electronic Journal. Available at: https://ssrn.com/ abstract=2269124.

Crespi-Cladera R., Pascual-Fuster B. (2015). Executive directors' pay, networks and operating performance: The influence of ownership structure. Journal of Accounting and Public Policy, vol. 34, no. 2, pp. 175-203.

Denis D.J., Denis D.K. (1995). Performance changes following top management dismissals. The Journal of Finance, vol. 50, no. 4, pp. 1029-1057.

Donaldson L. (1985). In defence of organisation theory. A reply to the critics. Cambridge, UK: Cambridge University Press.

Donaldson L. (1990). The ethereal hand: Organizational economics and management theory. Academy of Management Review, vol. 15, no. 3, pp. 369-381.

Eisenhardt K.M. (1989). Agency theory: An assessment and review. Academy of Management Review, vol. 14, no. 1, pp. $57-74$.

Etzioni A. (1975). Comparative analysis of complex organizations. N.Y.: Simon and Schuster.

Fee C.E., Hadlock C.J., Huang J., Peirce J.R. (2017). Robust models of CEO turnover: New evidence on relative performance evaluation. Review of Corporate Finance Studies, vol. 7, no. 1, pp. 70-100.

Fidrmucova J., Fidrmuc J. (2001). Firm Performance, CEO Turnover and Managerial Labor Market in the Czech Republic. Center for European Integration Studies (ZEI), vol. 466, p. 3066.

Fiordelisi F., Ricci O. (2014). Corporate culture and CEO turnover. Journal of Corporate Finance, vol. 28, pp. 66-82.

Freeman R.E. (2010). Strategic management: A stakeholder approach. Cambridge, UK: Cambridge University Press.

Gamson W.A., Scotch N.A. (1964). Scapegoating in baseball. American Journal of Sociology, vol. 70, no. 1, pp. 69-72.

Gao H., Harford J., Li K. (2017). CEO turnover - performance sensitivity in private firms. Journal of Financial and Quantitative Analysis, vol. 52, no. 2, pp. 583-611.

Gibson M.S. (2003). Is corporate governance ineffective in emerging markets? Journal of Financial and Quantitative Analysis, vol. 38, no. 1, pp. 231-250.

Goleman D. (1995). Emotional Intelligence. N.Y.: Bantam Books, Inc.

Hambrick D.C., Mason Ph.A. (1984). Upper echelons: The organization as a reflection of its top managers. Academy of Management Review, vol. 9, no. 2, pp. 193-206.

Herzberg F.M., Mausner B.B., Snyderman B. (1959). The motivation to work. N.Y.: John Wiley \& Sons.

Huson M.R., Malatesta P.H., Parrino R. (2004). Managerial succession and firm performance. Journal of Financial Economics, vol. 74, no. 2, pp. 237-275.

Jensen M.C. (2001). Value maximization, stakeholder theory, and the corporate objective function. Journal of Applied Corporate Finance, vol. 14, no. 3, pp. 8-21.

Jensen M.C., Meckling W.H. (1976). Theory of the firm: Managerial behavior, agency costs and ownership structure. Journal of Financial Economics, vol. 3, no. 4, pp. 305-360.

Jenter D., Kanaan F. (2015). CEO turnover and relative performance evaluation. The Journal of Finance, vol. 70, no. 5, pp. 21552184.

Jenter D., Lewellen K. (2017). Performance-Induced CEO Turnover. CEPR Discussion Paper No. DP12274.

Kaplan S.N., Klebanov M.M., Sorensen M. (2012). Which CEO characteristics and abilities matter? The Journal of Finance, vol. 67, no. 3, pp. 973-1007. 
Kato T., Long C. (2006). CEO turnover, firm performance, and enterprise reform in China: Evidence from micro data. Journal of Comparative Economics, vol. 34, no. 4, pp. 796-817.

Khanna N., Poulsen A.B. (1995). Managers of financially distressed firms: Villains or scapegoats? The Journal of Finance, vol. 50, no. 3, pp. 919-940.

Lindrianasari J.H., Hartono J. (2011). The Relationship between Accounting Performance and CEO Turnover: Evidence from Indonesia. Accounting\&Taxation, vol. 3, no. 2, pp. 97-107.

Lipman-Blumen J. (1997). Connective leadership: A new paradigm. Drucker Magazine, vol. 1, no. 1, pp. 12-19.

McClelland D.C. (1961). The Achieving Society. Oxford, England:Van Nostrand.

Muravyev A. (2017). Boards of directors in Russian publicly traded companies in 1998-2014: Structure, dynamics and performance effects. Economic Systems, vol. 41, no. 1, pp. 5-25.

Muravyev A. (2003). Turnover of senior managers in Russian privatised firms. Comparative Economic Studies, vol. 45, no. 2, pp. 148-172. DOI: https://doi.org/10.1057/palgrave.ces.8100008.

Mussalli G.D., Cukurova S. (2018). Appointing an Interim CEO? Not surprising if you failed the corporate governance test. Pensions\&Investments, August 16. Available at: https://www.pionline.com/article/20180816/ONLINE/180819977/commentary-appointing-an-interim-ceo-not-surprising-if-you-failed-the-corporate-governance-test.

Penrose E. (1955). Limits to the Growth and Size of Firms. American Economic Review, vol. 45, no. 2, pp. 531-543.

Penrose E.T. (2009). The Theory of the Growth of the Firm. Oxford: Oxford University Press.

Pratt J.W., Zeckhauser R., Arrow K.J. (1985). Principals and agents: The structure of business. Cambridge, MASS: Harvard University Press.

Sargut G., McGrath R.G. (2011). Learning to live with complexity. Harvard Business Review, vol. 89, no. 9, pp. 68-76.

Setiawan D., Phua L.K., Chee H.K. (2013). CEO turnover and market reaction in Indonesia. Indonesian Capital Market Review, vol. 5, no. 2, pp. 85-94.

Shen W., Cannella A.A.Jr. (2002). Revisiting the Performance Consequences of CEO Succession: The Impacts of Successor Type, Postsuccession Senior Executive Turnover, and Departing CEO Tenure. The Academy of Management Journal, vol. 45, no. 4, pp. 717-733.

Silverman D. (1970). The Theory of Organisations. L.: Heinemann.

Stacey R.D. (1995). The science of complexity: An alternative perspective for strategic change processes. Strategic Management Journal, vol. 16, no. 6, pp. 477-495.

Williamson O.E. (1985). The Economic Institutions of Capitalism. N.Y.: Simon and Schuster.

Zhang P., Wierschem D., Mendez Mediavilla F.A. (2016). An empirical investigation on CEO turnover in IT firms and firm performance. Journal of International Technology and Information Management, vol. 25, no. 2, p. 5.

\title{
Information about the authors
}

\section{Svetlana V. OREKHOVA}

Dr. Sc. (Econ.), Professor, Head of Enterprises Economics Dept. Ural State University of Economics (62/45 8 Marta/Narodnoy Voli St., Ekaterinburg, 620144, Russia). E-mail: bentarask@list.ru.

\section{Larisa Sh. KUDIN}

Sr. Lecturer of Enterprises Economics Dept. Ural State University of Economics (62/45 8 Marta/Narodnoy Voli St., Ekaterinburg, 620144, Russia). E-mail: larisakudin@yandex.ru.

\section{Aleksandra V. KUPERA}

Cand. Sc. (Econ.), Associate Professor of Department of Economics. Higher School of Economics in Saint Petersburg (3/1A Kantemirovskaya St., Saint Petersburg, 194100, Russia). E-mail: avkupera@gmail.com.

\section{Сменяемость генерального директора и результативность компании: взаимосвязь и эмпирические оценки}

\author{
С.В. Орехова, М.Ш. Кудин, А.В. Купера
}

Аннотация. Решение проблем организационной эффективности во многом зависит от качества системы корпоративного управления. Одним из ее аспектов выступают характеристики и действия генерального директора компании. Статья посвящена оценке влияния смены генерального директора на результативность деятельности компании. На основе критического анализа существующих подходов, описывающих его роль и влияние на успешность бизнеса, обосновано методологическое поле исследования: синтез теорий неоинституционализма, организации и стратегического управления. Метод исследования - панельная регрессия с фиксированными эффектами. Информационную базу составили данные 54341 российской акционерной компании с 2006 по 2017 г. Различные спецификации базовой модели позволили выявить статистически значимую отрицательную связь 
между изменением выручки и фактом смены генерального директора в краткосрочном периоде. Полученные результаты подтвердили положения теории роста фирмы в части необходимости адаптации генерального директора к внешней и внутренней среде компании в течение длительного периода. Также обнаружено, что иностранные генеральные директора и директора-собственники (акционеры) быстрее приспосабливаются к новой должности, что ускоряет рост показателей результативности бизнеса. Вместе с тем выявлено, что ухудшение результатов деятельности компании имеет краткосрочный эффект. Данный факт означает, что советам директоров не следует принимать поспешных решений о смене генерального директора после непродолжительного периода его работы.

Ключевые слова: корпоративное управление; генеральный директор; результативность компании; сменяемость директора; акционерные общества; российские компании.

JEL Classification: $10, \mathrm{G} 30$

Аата поступления статьи: 18 апреля 2019 г.

Ссылка для цитирования: Орехова С.В., Кудин Л.Ш., Купера А.В. Сменяемость генерального директора и результативность компании: взаимосвязь и эмпирические оценки // Управленец. 2019. Т. 10. № 4. С. 2-13. DOI: 10.29141/2218-5003-2019-104-1.

\section{Источники}

Гольцман М.М. (2000). Эмпирический анализ смены менеджеров в российских фирмах. М.: Рос. экон. шк.

Долгопятова Т.Г. (2011). Наемные менеджеры в российских компаниях: эмпирические свидетельства на фоне кризиса // Финансы и бизнес. № 4. С. 149-165.

Долгопятова Т.Г. (2007). Эмпирический анализ корпоративного контроля в российских компаниях: когда крупные акционеры отходят от исполнительного управления? // Российский журнал менеджмента. Т. 5. № 3. С. 27-52.

Дубровский В.Ж., Романова О.А., Татаркин А.И., Ткаченко И.Н. (2004). Динамика корпоративного развития. М.: Наука.

Капелюшников Р.И. (2015). Мобильность и идентичность руководителей российских промышленных предприятий // М: Изд. дом Высш. шк. экономики.

Капелюшников Р.И., Демина Н.В. (2005). Обновление высшего менеджмента российских промышленных предприятий: свидетельства «Российского экономического барометра» // Российский журнал менеджмента. Т. 3. № 3. С. $27-42$.

Менар К. (1996). Экономика организаций. М. : ИНФРА-М.

Муравьев А.А., Талавера А.В., Билык О.А., Гречанюк Б.В. (2009). Результаты деятельности фирм и смена менеджеров в Украине // Российский журнал менеджмента. Т. 7. № 4. С. 13-32.

Рачинский А.А. (2001). Смена менеджеров и эффективность компаний в России. М.: Рос. экон. шк.

Рощин С.Ю., Солнцев С.А. (2005). Рынок труда топ-менеджеров в России: между внешним наймом и внутренним продвижением // Российский журнал менеджмента. Т. 3. № 4. С. 11-28.

Солнцев С.А. (2013). Изменения на российском рынке труда топ-менеджеров в период кризиса: свидетельства эмпирического исследования // Российский журнал менеджмента. Т. 11. № 1. С. 3-18.

Тичи Н., Деванна М.А. (1990). Лидеры реорганизации (из опыта американских корпораций). М.: Экономика.

Ткаченко И.Н. (2001). Эволюция внутрифирменных корпоративных отношений. Екатеринбург: Ин-т экономики УрО РАН.

Ткаченко И.Н., Злыгостев А.А. (2018). Оценка вклада стейкхолдеров в стоимость компании: пример российского банковского сектора // Управленец. Т. 9. № 4. С. 40-52. DOI: 10.29141/2218-5003-2018-9-4-5.

Яковлев А.А., Данилов Ю.А., Симачев Ю.В. Глобальный финансовый кризис и корпоративное управление // Российский журнал менеджмента. Т. 8. № 2. С. 21-34.

Argyris C., McGregor D. (1960). The Human Side of Enterprise. N.Y.: McGraw-Hill.

Barney J.B. (1990). The debate between traditional management theory and organizational economics: Substantive differences or intergroup conflict? Academy of Management Review, vol. 15, no. 3, pp. 382-393.

Benmelech E., Frydman C. (2015). Military CEOs. Journal of Financial Economics, vol. 117, no. 1, pp. 43-59.

Berle A., Means G. (1932). The modern corporation and private property. N.Y.: McMillan.

Bertrand M., Schoar A. (2003). Managing with style: The effect of managers on firm policies. The Quarterly Journal of Economics, vol. 118, no. 4, pp. 1169-1208.

Bonnier K.A., Bruner R.F. (1989). An analysis of stock price reaction to management change in distressed firms. Journal of Accounting and Economics, vol. 11, no. 1, pp. 95-106.

Buckley P.J., Casson M. (2010). Edith Penrose's theory of the growth of the firm and the strategic management of multinational enterprises. In: Buckley P.J., Casson M. The Multinational Enterprise Revisited. L.: Palgrave Macmillan. Pp. 277-300.

Burns J.M. (1978). Leadership. N.Y.: Harper \& Row.

Byrka-Kita K., Czerwiński M., Preś-Perepeczo A. (2017). Stock market reaction to CEO appointment - preliminary results. Journal of Management and Business Administration, vol. 25, no. 2, pp. $23-42$.

Cornelli F., Karakaş O. (2015). CEO turnover in LBOs: The role of boards. SSRN Electronic Journal. Available at: https://ssrn.com/abstract $=2269124$

Crespí-Cladera R., Pascual-Fuster B. (2015). Executive directors' pay, networks and operating performance: The influence of ownership structure. Journal of Accounting and Public Policy, vol. 34, no. 2, pp. 175-203.

Denis D.J., Denis D.K. (1995). Performance changes following top management dismissals. The Journal of Finance, vol. 50, no. 4, pp. 1029-1057.

Donaldson L. (1985). In defence of organisation theory. A reply to the critics. Cambridge, UK: Cambridge University Press.

Donaldson L. (1990). The ethereal hand: Organizational economics and management theory. Academy of Management Review, vol. 15, no. 3, pp. 369-381.

Eisenhardt K.M. (1989). Agency theory: An assessment and review. Academy of Management Review, vol. 14, no. 1, pp. 57-74.

Etzioni A. (1975). Comparative analysis of complex organizations. N.Y.: Simon and Schuster. 
Fee C.E., Hadlock C.J., Huang J., Peirce J.R. (2017). Robust models of CEO turnover: New evidence on relative performance evaluation. Review of Corporate Finance Studies, vol. 7, no. 1, pp. 70-100.

Fidrmucova J., Fidrmuc J. (2001). Firm Performance, CEO Turnover and Managerial Labor Market in the Czech Republic. Center for European Integration Studies (ZEI), vol. 466, p. 3066.

Fiordelisi F., Ricci O. (2014). Corporate culture and CEO turnover. Journal of Corporate Finance, vol. 28, pp. 66-82.

Freeman R.E. (2010). Strategic management: A stakeholder approach. Cambridge, UK: Cambridge University Press.

Gamson W.A., Scotch N.A. (1964). Scapegoating in baseball. American Journal of Sociology, vol. 70, no. 1, pp. 69-72.

Gao H., Harford J., Li K. (2017). CEO turnover - performance sensitivity in private firms. Journal of Financial and Quantitative Analysis, vol. 52, no. 2, pp. 583-611.

Gibson M.S. (2003). Is corporate governance ineffective in emerging markets? Journal of Financial and Quantitative Analysis, vol. 38, no. 1, pp. 231-250.

Goleman D. (1995). Emotional Intelligence. N.Y.: Bantam Books, Inc.

Hambrick D.C., Mason Ph.A. (1984). Upper echelons: The organization as a reflection of its top managers. Academy of Management Review, vol. 9, no. 2, pp. 193-206.

Herzberg F.M., Mausner B.B., Snyderman B. (1959). The motivation to work. N.Y.: John Wiley \& Sons.

Huson M.R., Malatesta P.H., Parrino R. (2004). Managerial succession and firm performance. Journal of Financial Economics, vol. 74, no. 2, pp. 237-275.

Jensen M.C. (2001). Value maximization, stakeholder theory, and the corporate objective function. Journal of Applied Corporate Finance, vol. 14, no. 3, pp. 8-21.

Jensen M.C., Meckling W.H. (1976). Theory of the firm: Managerial behavior, agency costs and ownership structure. Journal of Financial Economics, vol. 3, no. 4, pp. 305-360.

Jenter D., Kanaan F. (2015). CEO turnover and relative performance evaluation. The Journal of Finance, vol. 70, no. 5, pp. 2155-2184.

Jenter D., Lewellen K. (2017). Performance-Induced CEO Turnover. CEPR Discussion Paper No. DP12274.

Kaplan S.N., Klebanov M.M., Sorensen M. (2012). Which CEO characteristics and abilities matter? The Journal of Finance, vol. 67, no. 3 , pp. 973-1007.

Kato T., Long C. (2006). CEO turnover, firm performance, and enterprise reform in China: Evidence from micro data. Journal of Comparative Economics, vol. 34, no. 4, pp. 796-817.

Khanna N., Poulsen A.B. (1995). Managers of financially distressed firms: Villains or scapegoats? The Journal of Finance, vol. 50, no. 3 , pp. 919-940.

Lindrianasari J.H., Hartono J. (2011). The Relationship between Accounting Performance and CEO Turnover: Evidence from Indonesia. Accounting\&Taxation, vol. 3, no. 2, pp. 97-107.

Lipman-Blumen J. (1997). Connective leadership: A new paradigm. Drucker Magazine, vol. 1, no. 1, pp. 12-19.

McClelland D.C. (1961). The Achieving Society. Oxford, England: Van Nostrand.

Muravyev A. (2017). Boards of directors in Russian publicly traded companies in 1998-2014: Structure, dynamics and performance effects. Economic Systems, vol. 41, no. 1, pp. 5-25.

Muravyev A. (2003). Turnover of senior managers in Russian privatised firms. Comparative Economic Studies, vol. 45, no. 2, pp. $148-172$. DOI: https://doi.org/10.1057/palgrave.ces.8100008.

Mussalli G.D., Cukurova S. (2018). Appointing an Interim CEO? Not surprising if you failed the corporate governance test. Pensions\&Investments, August 16. Available at: https://www.pionline.com/article/20180816/ONLINE/180819977/commentaryappointing-an-interim-ceo-not-surprising-if-you-failed-the-corporate-governance-test.

Penrose E. (1955). Limits to the Growth and Size of Firms. American Economic Review, vol. 45, no. 2, pp. 531-543.

Penrose E.T. (2009). The Theory of the Growth of the Firm. Oxford: Oxford University Press.

Pratt J.W., Zeckhauser R., Arrow K.J. (1985). Principals and agents: The structure of business. Cambridge, MASS: Harvard University Press.

Sargut G., McGrath R.G. (2011). Learning to live with complexity. Harvard Business Review, vol. 89, no. 9, pp. 68-76.

Setiawan D., Phua L.K., Chee H.K. (2013). CEO turnover and market reaction in Indonesia. Indonesian Capital Market Review, vol. 5 , no. 2, pp. 85-94.

Shen W., Cannella A.A.Jr. (2002). Revisiting the Performance Consequences of CEO Succession: The Impacts of Successor Type, Postsuccession Senior Executive Turnover, and Departing CEO Tenure. The Academy of Management Journal, vol. 45, no. 4, pp. 717-733.

Silverman D. (1970). The Theory of Organisations. L.: Heinemann.

Stacey R.D. (1995). The science of complexity: An alternative perspective for strategic change processes. Strategic Management Journal, vol. 16, no. 6, pp. 477-495.

Williamson O.E. (1985). The Economic Institutions of Capitalism. N.Y.: Simon and Schuster.

Zhang P., Wierschem D., Mendez Mediavilla F.A. (2016). An empirical investigation on CEO turnover in IT firms and firm performance. Journal of International Technology and Information Management, vol. 25, no. 2, p. 5.

\section{Информация об авторах}

\section{ОРЕХОВА Светлана Владимировна}

Аоктор экономических наук, профессор, заведующий кафедрой экономики преАприятий. Уральский государственный экономический университет (620144, РФ, г. Екатеринбург, ул. 8 Марта/Народной Воли, 62/45). E-mail: bentarask@list.ru.

\section{КУАИН Аариса Шарифьяновна}

Старший преподаватель кафедры экономики предприятий. Уральский государственный экономический университет (620144, РФ, г. Екатеринбург, ул. 8 Марта/Народной Воли, 62/45). E-mail: larisakudin@yandex.ru.

\section{КУПЕРА Александра Валерьевна}

Кандидат экономических наук, Аоцент Аепартамента экономики. Высшая школа экономики в Санкт-Петербурге (194100, РФ, г. Санкт-

Петербург, ул. Кантемировская, 3/1A). E-mail: avkupera@gmail.com. 